\author{
Katarzyna Anna LEWKOWICZ-GRZEGORCZYK, PhD \\ Faculty of Economics and Finance, University of Bialystok \\ e-mail: k.grzegorczyk@uwb.edu.pl \\ ORCID: 0000-0002-9060-7812
}

DOI: 10.15290/OES.2021.04.106.07

\title{
THE CONCEPT OF FAIRNESS AS A CRITERION FOR THE ASSESSMENT OF THE PERSONAL INCOME TAX IN POLAND ${ }^{1}$
}

\begin{abstract}
Summary
Purpose - The aim of the article is to present the essence of tax justice in relation to the personal income tax in Poland.

Research method - The realisation of the aim required using the method of descriptive and comparative analysis to assess the fairness of charging the personal income tax.

Results - The results of the empirical study on the personal tax structure point to the progressive tax as the one which better fulfils the concept of tax justice. The common acceptance of the tax progression confirms the deeply rooted sense of vertical equity in the Polish society. According to this, higher taxes should be paid by the rich, while the less wealthy should be charged with lower taxes. Unfortunately, the structure of the personal income tax in Poland does not reflect this. On the basis of the evolution of the PIT tax structure, it is possible to determine flattening of the progression due to the introduction of the two-stage tax scale. What is more, one may experience frequent ethical doubts connected with tax exemptions, and especially with the rules of granting them.

Originality / value / implications / recommendations - Author's own evaluation of the personal income tax in terms of tax fairness.
\end{abstract}

Keywords: personal income tax, tax exemption, tax fairness

JEL Classification: D63, H24, H31, H53, K34

\section{Introduction}

Nowadays, the concept of the tax system fairness is taken into consideration more and more often. The interpretation of the tax fairness rules has always been a controversial one. Currently, while considering the fairness norm, it is common to reject the original patterns, which regarded the tax system as fair if it was characterized by the universality and equity of taxation. On one hand, it is assumed that the fair tax needs to be personalized and consider many factors which influence its amount, such as: the tax payer's age, the ability to work, the number of depen-

1 Article received on 19 June 2021, accepted on 24 September 2021. 
dent children, the character of performed work. Personalization mainly concerns the income tax from natural persons. The concept of personalization in the personal income tax system means adjusting the amount of tax burden to the tax payer's individual abilities through introducing the progressive tax scale, a tax-free amount and tax breaks and exemptions [Zieliński, 2019, p. 91].

In the subject literature, it is emphasized that the idea of tax fairness should be the determinant of the personalization level of the personal income tax. However, it is widely known that not all the elements of the personal income tax structure are in line with it. The article presents considerations on the realization of the fairness idea through the personalization tools in the personal income tax in Poland.

Taxes are of great importance for the individual and for the proper functioning of the society. Therefore, they must 'stem' from justice [Kiwak, 2006, p. 86]. In the theory of taxation, fairness - which is the main subject of considerations - is directly reflected in the adopted taxation technique and the structure of the tax system. Efficient functioning of the tax system thanks to the proper structure of particular taxes is the basis of the proper realization of the state's tasks. Taking this into consideration, the paper verifies the research hypothesis which claims that thanks to the proper structure, the personal income tax can realize the tax fairness idea.

Income taxes are the price the citizens pay for the existence of the state and for the public goods that it provides. Due to the fact that in the case of the personal income tax there is a change in the tax payer's income, the income tax plays not only a fiscal, but also a redistributive function ${ }^{2}$. Taxes are not only the method of paying for government services and public goods. Taxes are also the most important tool for implementing their concept of social justice by the political system [Murphy, Nagel, 2002, p. 3].

The aim of the article is the attempt to present the realization of the fairness idea on the basis of the selected elements of the personal income tax structure in Poland. The paper was prepared on the basis of literature studies and of the analysis of statistical data concerning tax return from natural persons published annually by the Ministry of Finance.

\footnotetext{
2 Taxes change the amount of resources available to each tax payer, and the relation between the income before and after taxation, between different groups of tax payers. In consequence, a question arises in what way it is possible to measure disparities generated by taxation. Gini's coefficient is used to measure disparities, showing the possible existence of three income taxation effects. Firstly, a horizontal one - the same income, different tax. Secondly, a vertical one - different income, different tax, and thirdly, reranking - after taxation, the tax payer changes their income group. According to Aronson and Lambert [1994], the greatest importance should be assigned to the vertical effect, which results from using progressive income taxation, which retains the income order from before the taxation. Additional information: [Aronson, Lambert, 1994; Aksman, 2010; Kośny, Mazurek, 2011].
} 


\section{The concept and scope of tax fairness}

The concept of tax fairness has been perceived differently in different times and 'relativized to each era' [Gomułowicz, 2001, p. 9]. According to 'the choice of taxation rules is finally a derivative of both the philosophical concept of the state and society, and the pragmatic considerations connected with the applicable income taxation techniques'. Moreover, as T. Sommer [2006, p. 104] claimed, the rule of 'ability to pay' is 'currently the most important rule behind the really functional taxes in the Western world. It is the real basis for obtaining the majority of income by the countries'.

The choice of economic quantities reflecting the tax ability of an individual is one of the oldest issues in the taxation theory. Selecting a proper subject of taxation should be preceded by, on one hand, defining the group of goals of the tax system ${ }^{3}$. However, on the other hand, selecting a proper subject of taxation should be able to consider individual payment abilities of particular tax payers. In consequence, tax burdens should be distributed in a fair way. In the theory of public finance, two concepts of the proper tax burden distribution have been formulated: the principle of payment (tax) ability and the principle of benefit (or equivalence). Those two main concepts may justify tax collection and be the bases of the tax burden distribution [Dziemianowicz, 2007, p. 37]. It may be assumed that the principle of equivalence requires that each citizen should be burdened with taxes proportionally to the benefits they acquire from the state's activity, while the principle of payment ability justifies charging taxes in accordance with the individual ability to pay taxes.

It should be emphasizes that tax fairness is determined by the morally acceptable taxation limit. Its realisation is expressed through tax universality and equity, while taking into consideration a tax payer's material situation [Kosikowski, Ruśkowski, 2006, p. 497]. Tax universality and equity should make the citizens aware that the burden of maintaining the state is carried by everyone. On the other hand, a fair distribution of tax burden takes into consideration a tax payer's ability to carry that burden.

The concept of universality may be undermined when some groups of tax payers are treated in a different way than others. The problem arises in the case of tax breaks and exemptions. The system of breaks and exemptions, which is integrated into tax progression - especially in the case of the personal income tax - alters significantly the distribution of taxes paid in real life, in comparison with the taxes resulting from the distribution of the income amount. It contradicts the principle of equity which recommends to treat all the tax payers in the same situation in the same way [Gomułowicz, 2001, p. 34].

Searching for further answers to the questions regarding tax fairness, one can adopt two evaluation approaches: the objective and the subjective one [Famulska, 1996, pp. 3-4]. The objective approach to fairness has a particular practical value, as

\footnotetext{
3 However, 'the choice of particular goals automatically limits the collection of applicable fiscal structures’ [Wyszkowski, 2010, p. 229].
} 
this approach is usually adopted by the public authorities, while charging taxes. On the other hand, the subjective fairness is connected with the tax payers' perception of fair taxes ${ }^{4}$. Tax policy should take direction which would allow to achieve the convergence between the objective and the subjective fairness. In economics, the first of them is the dominant one. Economists who define the objective fairness of the tax system refer to two criteria at the same time: horizontal and vertical fairness.

Horizontal fairness assumes that the subjects in a similar or identical situation are charged with the same taxes. Applying this principle is only seemingly simple. It is not reflected in material taxes but in more complex personal taxes, which take into account the tax payer's individual situation, e.g. health condition, the number of dependent persons. According to M. Kośny [2007, p. 68], applying this rule while constructing the tax system may lead to horizontal injustice. According to the author, taking into consideration various features while determining similarity, may lead to considerably varied results (it relates, among others, to the rationale of taking into account the family situation of the tax payer).

Vertical fairness in taxation assumes that wealthier subjects carry a heavier burden than the subjects in worse financial situation [Famulska, 1996, pp. 3-4]. This means that tax payers in better financial situation should pay higher taxes. The analysis of this principle requires to define what is meant by the tax payer's better situation (it might mean higher income) or 'higher taxes'. It also requires the answer to this question: 'should the tax system affect income distribution within the population, and if so, how and to what degree?' [Kośny, 2007, p. 69]. The vertical fairness principle, i.e. diversification of taxation due to the tax payer's income situation, is implemented in Poland mainly through the progressive income tax from natural persons.

\section{Realisation of the fairness concept in structuring the personal income tax in Poland}

In the current tax system, progressive tax values are undoubtedly one of the most important elements of structuring the personal income tax, which allow to apply the vertical fairness concept in taxation. At the same time, according to the analysis of the statistical data presented in table 1, in 2009, a great majority, namely $98.41 \%$ of tax payers in Poland, were classified in the first income range.

\footnotetext{
4 Psychologists dealing with taxes are mostly interested in the subjective fairness of the tax system what people perceive as right and fair. Surveys conducted in Poland show that the tax system is perceived as unfair by $70 \%$ of Poles. Their sense of injustice may be also influenced by the complicated taxation laws. There are also people who perceive the Polish tax system as rather fair or completely fair. They constitute about $20 \%$. What is most interesting is, however, the fact that about $10 \%$ of the people surveyed have no opinion on the issue. According to the research, when asked about tax fairness, tax payers usually equate fairness with lowering tax burden or its full elimination, especially in the case of the taxes which concern them directly. On the other hand, they are for higher taxation of other social groups. More information: [Lewkowicz-Grzegorczyk, 2011, pp. 166-168].
} 
TABLE 1

Taxpayers of personal income tax and due tax according to the tax scale ranges in 2009-2019

\begin{tabular}{|c|c|c|c|c|}
\hline Year & Tax range & $\begin{array}{c}\text { Number } \\
\text { of taxpayers } \\
\text { (in thousand) }\end{array}$ & $\begin{array}{l}\text { Structure } \\
\text { of taxpayers } \\
\text { (in \%) }\end{array}$ & $\begin{array}{c}\text { Tax due } \\
\text { (in \%) }\end{array}$ \\
\hline \multirow{3}{*}{2009} & I & 24020 & 98.41 & 76.97 \\
\hline & II & 387 & 1.59 & 23.03 \\
\hline & Total & 24407 & 100 & 100 \\
\hline \multirow{3}{*}{2010} & I & 24094 & 98.11 & 77.32 \\
\hline & II & 464 & 1.89 & 22.68 \\
\hline & Total & 24558 & 100 & 100 \\
\hline \multirow{3}{*}{2011} & I & 23804 & 97.86 & 76.28 \\
\hline & II & 521 & 2.14 & 23.72 \\
\hline & Total & 24325 & 100 & 100 \\
\hline \multirow{3}{*}{2012} & I & 23433 & 97.69 & 73.44 \\
\hline & II & 554 & 2.31 & 26.56 \\
\hline & Total & 23987 & 100 & 100 \\
\hline \multirow{3}{*}{2013} & I & 23753 & 97.53 & 75.28 \\
\hline & II & 602 & 2.47 & 24.72 \\
\hline & Total & 24355 & 100 & 100 \\
\hline \multirow{3}{*}{2014} & I & 23735 & 97.3 & 74.45 \\
\hline & II & 658 & 2.7 & 25.55 \\
\hline & Total & 24393 & 100 & 100 \\
\hline \multirow{3}{*}{2015} & $\mathrm{I}$ & 23880 & 97.11 & 74.12 \\
\hline & II & 710 & 2.89 & 25.88 \\
\hline & Total & 24590 & 100.00 & 100 \\
\hline \multirow{3}{*}{2016} & $\mathrm{I}$ & 23999 & 96.96 & 73.89 \\
\hline & II & 753 & 3.04 & 26.11 \\
\hline & Total & 24752 & 100.00 & 100 \\
\hline \multirow{3}{*}{2017} & $\mathrm{I}$ & 24090 & 96.54 & 72.29 \\
\hline & II & 864 & 3.46 & 27.71 \\
\hline & Total & 24954 & 100.00 & 100 \\
\hline \multirow{3}{*}{2018} & $\mathrm{I}$ & 24607 & 95.94 & 70.3 \\
\hline & II & 1041 & 4.06 & 29.7 \\
\hline & Total & 25648 & 100.00 & 100 \\
\hline \multirow{3}{*}{2019} & $\mathrm{I}$ & 24280 & 95.16 & 67.88 \\
\hline & II & 1234 & 4.84 & 32.12 \\
\hline & Total & 25514 & 100.00 & 100 \\
\hline
\end{tabular}

Source: own elaboration on the basis: [Information from the Ministry of Finance...].

Therefore, tax progression concerned only 1.59\%. Almost $77 \%$ of PIT tax income came from tax payers classified in the first tax range, and only $23 \%$ from those in the second income range. Moreover, the data presented in table 1 confirms that the share of tax payers in the first tax range in 2019 decreased by 3 p.p. in 
comparison with 2009. The share of tax payers in the second range in the studied period increased by 3 p.p. Those changes should be seen as positive, because, according to the data from 2019, $67 \%$ of PIT tax income came from tax payers classified in the first tax range, while $32 \%$ from those in the second income range.

As a rule, the progressive tax scale should burden most the highest income. However, the practice does not follow the theory and the two-tier tax progression, which has been in place since 2009, has led to their excessive capacity. As a result, the first tax range was characterized by proportional taxation which included the income of almost $98 \%$ tax payers. A two-tier tax scale resulted in the fact that former tax payers from the second range moved to the first one with an 18\% tax rate, while the tax payers from the third range (with a $40 \%$ tax rate in 2008) were charged with a $32 \%$ tax rate. Generally, in Poland there is a tendency to gradually decrease tax progression. Since January $1{ }^{\text {st }}, 2009$, there have been two tax rates $(18 \%$ and $32 \%$ ). As a result, the tax progression for the tax payers in the second as well as in the third tax rate range diminished. In 2019, 18\% tax rate was replaced by $17 \%$ tax rate, this time, to the benefit of tax payers from the first tax range. Additionally, since 2019, a solidarity levy has applied instead of the third tax range, in the case of income above PLN $1 \mathrm{mln}$. This is a levy which the wealthiest tax payers have been charged with, in accordance with the vertical fairness principle.

From the point of view of the need to efficiently achieve fiscal and non-fiscal goals of the tax policy, taxation should be even and the burden on the tax payers moderate. Too high progressive rates hinder tax payers' motivation for more efficient work and increasing their income and assets, leading to lower savings and, in consequence, fewer possibilities of investment. Such actions may lead to wealthier tax payers' escape to countries with lower tax rates. As a result, the goal to distribute taxes according to the tax payers' financial capacity will not be achieved, and fiscal burdens will be carried mainly by the less wealthy or poor tax payers. In Poland tax burdens are still not distributed on tax payers equally enough to positively influence their behaviours and to enable efficient stimulation of economic activity, and, consequently, reaching higher income.

In the present conditions of a two-tier scale of income tax from natural persons, when the first range includes the vast majority of tax payers, it cannot be stated that this personalization tool properly fulfils its assigned function, while complying with the principle of financial capacity. If we add the fact that a part of income - including the income from monetary assets and the income from the non-agricultural economic activity of natural persons may be charged with linear tax, so they are excluded from progression, then this kind of exceptions from the general taxation rules definitely does not guarantee a socially just distribution of tax burdens. Presented examples prove the unfair treatment of different income sources by the legislator. Tax payers who achieve their income from employment agreements have much fewer privileges than those who achieve their income from economic activity

Some important issues in terms of tax fairness are also the tax-free income amount and the tax-reducing amount. The tax-free income amount (so-called, taxfree minimum) amounted to PLN 3091 in the years 2009-2016, but in 2017 it was 
raised to PLN 6600 and in 2018 to PLN 8000. It is also worth noticing that since 2017, the tax-reducing amount has become degressive. It means that a higher taxreducing amount applies to a tax payer with the income of PLN 8000-13000, and a lower to one with the income over PL 85 528. In the case of income over PLN 127000 the tax-free amount does not apply.

Due to the fact that during the whole analysed period, the tax-free amount did not correspond to the, so-called, minimum standard of living of a tax-payer, according to the announcements of New Deal, since 2022 the tax-free amount is to amount to 30 000. The increase of the tax-free amount will certainly improve the situation of people with minimum wages. Due to this fact, the proposed change should be seen as a positive one. This will result in lower taxes for those with the lowest earnings, will simplify the system (no complicated calculations connected with the tax-free amount - the tax-free amount's degressive tendency was unfair) and will introduce the tool for the tax-free amount valorisation in the future. At the same time, it has been announced that the tax range will be raised to PLN 120 000, which will again favour wealthier tax-payers, who were previously charged with a $32 \%$ tax rate. This solution seems to negate the principle of vertical fairness.

The goal of the tax reform designed in New Deal is to lower tax burdens from lower incomes, the increase in the progression of the tax and premium wedge, and eliminating the injustice in health care insurance. In general, the proposed solutions are to ensure the more just tax burden distribution. However, not all the changes e.g. raising the tax range to PLN 120000 - seem to fulfil those goals. Similarly, the proposed changes in, among others, settling the health insurance premiums, which are proposed in New Deal, are perceived by entrepreneurs as unfair and may discourage them from entrepreneurship. From 2022, the basis for the calculation of the health insurance premiums will be the entrepreneurs' actual income, instead of a flat-rate fee. Moreover, a part of the paid health insurance premium will no longer be tax-deductible for natural persons. As a result, this will mean a tax increase by 9 p.p., and will undermine the concept of linear taxation.

It needs to be emphasized that the actual progression of the personal income tax depends not only on the number and amount of rates or the tax scale ranges, but also on other elements of the tax structure, especially on tax exemptions. In the considerations regarding the taxation fairness, there arises a question whether tax exemptions, which are an exception to the taxation universality principle, do not contradict the taxation fairness principle. It is believed that tax exemptions play an important role in diminishing the tax burden and the tax progression. At the same time, the assessment of tax breaks and exemptions is extremely varied, i.e. they have both proponents as well as opponents. Some claim they perform two important functions. Firstly, they enable to consider the individual situation of a tax payer. Secondly, they can encourage the wealthiest to increase investments and savings. According to others, tax breaks and exemptions are discriminatory towards those who do not benefit from them. This interferes with the taxation universality principle. Tax exemption for a particular group of people means a greater tax burden for others. Developing the system of tax breaks interferes with taxation 
equity, and this might be the basis to state that tax legislation is unfair. Such a situation may arise when only the people with high income can benefit from tax exemptions. Moreover, tax privileges decrease revenues of the government budget.

It is worth remembering that all the elements in the personal income tax structure should reflect taxation fairness principles. Tax privileges in the form of tax breaks and exemptions should, at the same time, constitute the implementation of the constitutional law of the personal scope, realising the principles of taxation fairness, universality and equity. Taking this into consideration, the system of tax breaks and exemptions relating to the income tax from natural persons must respect and support the rules stemming from the Polish Constitution, including the principles resulting from its article 2, article 32 act 1, article 84 and article 217 [Marusik, 2018, pp. 67-91]. Unfortunately, tax breaks and exemptions of the income tax from natural persons, or subject and object exemptions often contradict those principles.

The personal income tax is a personal burden. A tax payer is every natural person who has an income. It can be said that it fulfils the basic rationale of horizontal equity, i.e. an equal treatment of equal incomes, despite the fact that the Polish structure of the income tax from natural persons contains numerous exceptions from this rule. The legislator excludes certain income categories from taxation (e.g. from agricultural business activity). As a result, payment ability of Polish tax payers is reflected in a limited way ${ }^{5}$.

\section{The assessment of tax deductions and exemptions in the income tax from natural persons in Poland, in view of the tax fairness concept}

A fair tax is a universal tax both from the personal and material point of view. A fair approach takes into consideration a balanced distribution of tax burdens depending on the financial capacity. At the same time, it should be assumed that tax fairness does not exclude tax privileges. It allows to introduce tax breaks and deductions if it is justified by a specific financial situation of the pertaining tax payers groups and if it does not discriminate other groups [Szołno-Koguc, 2016, p. 171]. That means that the concept of taxation fairness may be realised only through well-constructed breaks and exemptions, which are addressed only to chosen groups of tax payers characterized by low incomes, including large families, the disabled or those conducting business activity.

Tax exemptions regarding the income tax from natural persons may have a form of income deductions or tax deductions. Currently, the first group includes: donations, rehabilitation expenses, the return of unlawfully collected benefits, the

\footnotetext{
5 According to the regulations, the act does not apply to, among other: incomes from agricultural activity (apart from incomes from special sections of agricultural production), incomes from silviculture, incomes included in the regulations regarding inheritance and donations, incomes resulting from activities which cannot be the subject of a lawful contract, family allowances, a shipowner incomes charged with taxes according the regulations in the Tonnage Tax Act [Act, 1991, art. 2].
} 
Internet use expenses, thermo-modernisation expenses, deposits to personal pensions funds (IKZE) and other income deductions, including those on the basis of grandfather clause.

It is emphasized that those income tax deductions and exemptions for natural persons - of the redistributive or stimulating character - which have existed in Poland since 1991, have allowed some groups of tax payers to lower (or fully eliminate) their tax burden, directly influencing their income level. However, in the case of wealthier tax payers, exemptions and deductions mitigated tax progression, leading to the reversal of redistribution direction generally perceived as just. From this point of view, redistribution through exemptions and deductions in the income tax from natural persons may be perceived as contradictory to the tax fairness principle. Therefore, nowadays one can observe a tendency to limit the entitlement to tax exemptions. The exemption range that has been particularly limited pertains to breaks which used to be aimed at a wide group of tax payers, such as the Internet use exemption, where it is now possible to deduct expenses only in two consecutive years and only on condition that the tax payer did not benefit from this deduction in the preceding period [Act, 1991, art. 26, act 1, point 6a]. The interest deduction or investment deductions for entrepreneurs as well as many others were fully eliminated. On the other hand, the legislator introduced new exemptions, e.g. since 2012, there has been an exemption for those saving for the future pension [Act, 1991, art. 26 , act 1 , point $2 \mathrm{~b}$ ], which enables to deduct payments into a personal retirement fund; the legislator also changed the regulations regarding deductions and the deduction amounts pertaining child exemptions [Act, 1991, art. 27f], for the third and all the following children [Durczyńska, 2016, pp. 449-450].

The introductory assessment of deductions and exemptions in the income tax from natural persons in Poland - in terms of income taxation fairness - has been conducted through the analysis of the number of tax payers benefiting from them, depending on the amount of their income. Table 2 contains information regarding the percentage of people benefiting from tax deductions and exemptions in each tax period (for the years 2009-2018), and the deductions amounts. Due to the fact that in the analysed period most tax payers belonged to the first tax range, their percentage in benefiting from tax deductions and exemptions - and, as a result, deducted amounts - is prevailing.

\footnotetext{
${ }^{6}$ More information regarding the analysis of data regarding the share of tax and income deductions according to income ranges and the tax and income deductions structure according to entitlement in the period 2000-2015 [Lewkowicz-Grzegorczyk, 2019, pp. 137-152, 160-172].
} 
TABLE 2

Taxpayers of income tax from persons benefiting from tax deductions and exemptions in the years 2009-2019

\begin{tabular}{|c|c|c|c|c|c|c|}
\hline Year & Tax range & $\begin{array}{c}\text { Number } \\
\text { of tax payers } \\
\text { taking } \\
\text { advantage } \\
\text { of tax dedu- } \\
\text { ctions (in } \\
\text { thousands) }\end{array}$ & $\begin{array}{l}\text { Tax payers } \\
\text { taking } \\
\text { advantage } \\
\text { of tax } \\
\text { deductions } \\
\text { (in } \%)\end{array}$ & $\begin{array}{l}\text { Tax } \\
\text { deduction } \\
\text { amount } \\
\text { (amount in } \\
\text { PLN } \\
\text { million) }\end{array}$ & $\begin{array}{l}\text { Number of } \\
\text { tax payers } \\
\text { using } \\
\text { deductions } \\
\text { from inco- } \\
\text { me (in } \\
\text { thousands) }\end{array}$ & $\begin{array}{c}\text { Amount } \\
\text { to be } \\
\text { deducted } \\
\text { from } \\
\text { income } \\
\text { (amount } \\
\text { in PLN } \\
\text { million }\end{array}$ \\
\hline \multirow{3}{*}{2009} & I & 4426 & 97,07 & 5612 & 5342 & 5053 \\
\hline & II & 133 & 2,93 & 243 & 237 & 360 \\
\hline & Total & 4560 & 100,00 & 5855 & 5579 & 5413 \\
\hline \multirow{3}{*}{2010} & I & 4312 & 96,56 & 5569 & 5538 & 5134 \\
\hline & II & 154 & 3,44 & 279 & 316 & 323 \\
\hline & Total & 4465 & 100,00 & 5848 & 5854 & 5458 \\
\hline \multirow{3}{*}{2011} & I & 4315 & 96,05 & 5551 & 5455 & 5131 \\
\hline & II & 178 & 3,95 & 313 & 247 & 452 \\
\hline & Total & 4493 & 100,00 & 5864 & 5702 & 5838 \\
\hline \multirow{3}{*}{2012} & I & 4247 & 95,53 & 5498 & 5356 & 4924 \\
\hline & II & 199 & 4,47 & 337 & 275 & 466 \\
\hline & Total & 4446 & 100,00 & 5835 & 5631 & 5390 \\
\hline \multirow{3}{*}{2013} & $\mathrm{I}$ & 3986 & 97,27 & 5373 & 2113 & 2988 \\
\hline & II & 112 & 2,73 & 258 & 80 & 173 \\
\hline & Total & 4098 & 100,00 & 5631 & 2192 & 3160 \\
\hline \multirow{3}{*}{2014} & I & 3989 & 96,71 & 5384 & 1971 & 3135 \\
\hline & II & 136 & 3,29 & 379 & 106 & 342 \\
\hline & Total & 4125 & 100,00 & 5763 & 2077 & 3476 \\
\hline \multirow{3}{*}{2015} & $\mathrm{I}$ & 4009 & 96,37 & 5395 & 1967 & 3202 \\
\hline & II & 151 & 3,63 & 449 & 121 & 394 \\
\hline & Total & 4160 & 100,00 & 5844 & 2087 & 3596 \\
\hline \multirow{3}{*}{2016} & I & 4001 & 96,37 & 5429 & 1937 & 3230 \\
\hline & II & 151 & 3,63 & 469 & 128 & 367 \\
\hline & Total & 4152 & 100,00 & 5898 & 2065 & 3598 \\
\hline \multirow{3}{*}{2017} & I & 3798 & 95,64 & 5319 & 2049 & 3699 \\
\hline & II & 173 & 4,36 & 507 & 152 & 444 \\
\hline & Total & 3971 & 100,00 & 5826 & 2200 & 4143 \\
\hline \multirow{3}{*}{2018} & I & 3586 & 94,59 & 5243 & 2209 & 4121 \\
\hline & II & 205 & 5,41 & 597 & 205 & 544 \\
\hline & Total & 3791 & 100,00 & 5840 & 2413 & 4665 \\
\hline \multirow{3}{*}{2019} & I & no data & 0,00 & no data & no data & no data \\
\hline & II & no data & 0,00 & no data & no data & no data \\
\hline & Total & 3966 & 100,00 & 6025 & 2874 & 8125 \\
\hline
\end{tabular}

Source: own elaboration on the basis: [Information from the Ministry of Finance...]. 
It is clear that in the studied period, the percentage of tax payers benefiting from tax deductions in the first tax range amounted to, on average, over 95\% and in the second range $-4.5 \% 0^{7}$. It was observed that in 2013 - in comparison with the previous years - the percentage of tax payers benefiting from tax deductions in the first tax range increased to $97.27 \%$. On the other hand, the percentage of tax payers benefiting from tax deductions in the second tax range decreased to $2.73 \%$. It should be observed that this change for the benefit of the tax payers in the first range was mostly due to the change of the regulations regarding child deductions. Regardless, it is difficult to regard the structure as fair only due to the wide access to deductions and exemptions for the tax payers in the first tax range.

As it was mentioned before, exemptions in the income tax for natural persons usually act conversely in comparison with the progressive tax rates as they mitigate progression. It happens when the wealthy benefit from exemptions more often than others, even though they are aimed at everyone [Małecka-Ziembińska, 2006, p. 8]. One example is the child raising exemption, which one could apply for in the years 2007-2014, by proving an appropriate high level of tax burden. A low amount of tax in the yearly tax return form - in the case of tax payers with low incomes - made it impossible to receive the full amount of the deduction. The tax could be decreased to $0 \%$ level and the unspent part of the exemption could not be used in the following year. This situation occurred most often in the case of tax payers with the lowest income, which resulted in the sense of a lack of tax justice and a negative approach to the whole tax system [Ślesicka, 2009, p. 4]. Therefore, this tax deduction could not guarantee that the poorest families would benefit fully from the exemption. Moreover, the existence of this exemption did not improve income redistribution in such a way as to provide the people with lower income with the desired living standards. Another example might be the housing exemption - of a stimulating character - which was in existence in the years 2000-2012, and which was undoubtedly one of the most important tax exemptions. Due to the introduction of this exemption, the budget income was depleted by PLN 21 mld [Lewkowicz-Grzegorczyk, 2019, p. 166]. Housing expenses exemption was the one which during this whole period took the primary position, but in fact, mostly wealthier tax payers benefited from it, which was contradictory to the sense of taxation fairness.

In conclusion, it is worth noticing that the act on the income tax from natural persons in Poland [Act, 1991] allows to benefit from all tax privileges only for the tax payers settling taxes according to general rules. So the tax payers settling taxes according to rules of the lump sum on registered revenues or the tax card, those who chose to settle the non-agricultural business activity according to the $19 \%$ linear rate or the farmers who do not settle the income tax from natural persons at all, cannot benefit from the child exemption. Likewise, the R\&D exemption does not include tax payers charged according to the simplified rules. Therefore, the binding rules of granting those exemptions can be regarded as unjust.

7 The average from the years 2009-2018. 


\section{Conclusions}

The conducted considerations lead to believe that the personal income tax in Poland, in terms of fulfilling the taxation fairness principle, possesses both features that are compatible with as well as contradictory to that principle. The personal and direct character of the income tax from natural persons determines its crucial role in the fulfilling the fairness principle. It is disputable whether and how the tax burden should be adjusted to tax capacity. The application of the progressive scale might be regarded - with certain assumptions - as fair, but taking into consideration the lack of the actual tax-free minimum and a relatively high tax rate for people with the lowest income, this structure seems to lose its appeal.

Progressive taxation should enable to charge tax payers with low incomes with lower taxes. Unfortunately, in Poland, despite the valid progression of the income tax from natural persons, the less wealthy tax payers are still burdened with the highest costs of the state maintenance. The current ineffective tax progression of personal incomes results from the fact that in the years 2009-2019, on average $96 \%$ of tax payers were in the first range of the tax scale. This means that everyone in that group was charged with the same rate of taxes irrespective of their income. With the current two-tier taxation scale, it is definitely difficult to realise the concept of the fair income taxation.

The conducted analysis also shows that the tax progression in Poland is mitigated as a result of tax deductions and exemptions, especially when wealthier tax payers benefit from them, e.g. in the case of the child exemption in the years 20072014. Therefore, current changes in the structure of the child exemptions should be assessed as positive, i.e. more in line with the sense of the tax fairness.

The introduction of the income criterion and changes in the rules of this deduction seem to be an efficient solution. Thanks to this, its beneficiaries are large families, mainly tax payers in a worse financial situation who need more help from the state. At the same time, it seems that if the legislator made it possible for the tax payers settling taxes according to rules of the lump sum on registered revenues or the tax card to benefit from the child exemption or the R\&D exemption, such a solution would be much more just than the current one.

It should be emphasized that creating a tax system that would be fair to everyone is an extremely difficult task, especially when only specific groups of tax payers benefit from any tax reforms - also those in the structure of the personal income tax - at the expense of others. Therefore, the tax changes proposed in the Polish New Deal regarding, among others, the rules of settling healthcare insurance contributions, are not viewed positively by entrepreneurs who will lose most due to those changes. 


\section{References}

Act, 1991, Ustawa z dnia 26 lipca 1991 r. o podatku dochodowym od osób fizycznych (Dz.U. z 2010 r. Nr 51, poz. 307).

Aksman E., 2010, Redystrybucja dochodów i jej wplyw na spoleczny w Polsce w latach 1995 2007, Wydawnictwo Uniwersytetu Warszawskiego, Warszawa.

Aronson R.J., Lambert P.J., 1994, Decomposing the Gini coefficient to reveal the vertical, horizontal, and reranking effects of income taxation, "National Tax Journal", vol. 47(2), pp. 273-294, DOI: 10.1086/NTJ41789068.

Durczyńska M., 2016, Zakeres ulg w polskim systemie podatkowym, [w:] Dylematy reformy systemu podatkowego w Polsce, Dzwonkowski H., Kulicki J. (red.), Wydawnictwo Sejmowe, Warszawa.

Dziemianowicz R.I., 2007, Efektywność systemu opodatkowania rolnictwa, Wydawnictwo Uniwersytetu w Białymstoku, Białystok.

Famulska T., 1996, Sprawiedliwość podatkowa, „Przegląd Podatkowy” nr 5, s. 3-4.

Gomułowicz A., 2001, Zasada sprawiedliwości podatkowej, Dom Wydawniczy ABC, Warszawa.

Kiwak W., 2006, Sprawiedliwość podatków, [w:] Etyka a podatki i doradžtwo podatkowe, Ćwikliński H., Kubska-Maciejewska B., Geodecki Z. (red.), Wydawnictwo Wyższej Szkoły w Poznaniu, Poznań.

Kosikowski C., Ruśkowski E., 2006, Finanse publicz̨ne i prawo finansowe, Dom Wydawniczy ABC, Warszawa.

Kośny M., 2007, Podatki a dobrobyt społeczny, Wydawnictwo Akademii Ekonomicznej we Wrocławiu, Wrocław.

Kośny M., Mazurek E., 2011, Ocena niesprawiedliwości poziomej w podatku dochodowym od osób fizycznych, [w:] Statystyka i ryzyko. Spoteczna rola statystyki, Ostasiewicz W. (red.), Prace Naukowe Uniwersytetu we Wrocławiu, Wrocław.

Lewkowicz-Grzegorczyk K., 2011, Realizacja zasady sprawiedliwości na przyktadzie podatku dochodowego od osób fizycznych, „Optimum. Studia Ekonomiczne”, nr 1(49), s. 148-170.

Lewkowicz-Grzegorczyk K., 2019, Podatek dochodowy jako instrument redystrybucji dochodów w Polsce, CeDeWu, Warszawa.

Małecka-Ziembińska E., 2006, Podatek dochodowy jako regulator dochodów osób fizycznych w Polsce okresu transformacji ustrojowej, Wydawnictwo Akademii Ekonomicznej w Poznaniu, Poznań.

Marusik J., 2018, Konstytucyjne zasady sprawiedliwości, równości i powszechności opodatkowania a system ulg, zwolnien, odliczen, kwot wolnych $i$ kosatów w podatku dochodowym, „Studia BAS", nr 2(54), s. 67-91, DOI.10.31268/StudiaBAS.2018.04.

Murphy L., Nagel T., 2002, The myth of ownership, Oxford University Press, New York.

Sommer T., 2006, Czy da sie usprawiedliwic podatki? Czyli sposoby usprawiedliwiania podatków w swietle ideologii praw człowieka, 2S Media Sp. z o.o., Warszawa.

Szołno-Koguc J., 2016, Dylematy sprawiedliwości podatkowej - równość i powszechność opodatkowania a praymileje podatkowe, „Studia Ekonomiczne. Zeszyty Naukowe Uniwersytetu Ekonomicznego w Katowicach”, nr 294, s. 164-172. 
Ślesicka A., 2009, Ulga podatkowa na wychowanie drieci, „Infos BAS”, nr 5(52).

Wyszkowski A., 2010, Podatki pośrednie i dochodowe w systemie podatkonym, Wydawnictwo Uniwersytetu w Białymstoku, Białystok.

Zieliński R., 2019, Personalizacja w systemie obciażeń dochodón osób fizycznych w Polsce, Wolters Kluwer Warszawa. 